\title{
The Effect of Internal and External Motivation on Organizational Trust: A Case Study on a Sport Organization in Turkey
}

\author{
Sevim Güllü̈ ${ }^{1}$, Süleyman Şahin ${ }^{2} \&$ Esra Kızıloğlu ${ }^{3}$ \\ ${ }^{1}$ Istanbul University-Cerrahpasa, Faculty of Sport Sciences, Sport Management, Istanbul-Turkey \\ ${ }^{2}$ Bursa Uludag University, Faculty of Sport Sciences, Physical Education and Sport Teaching, Bursa-Turkey \\ 3 Konya Selcuk University, Faculy of Economy and Administrive Science, Busineess, Turkey \\ Correspondence: Sevim Güllü, Istanbul University-Cerrahpasa, Faculty of Sport Sciences, Sport Management, \\ Istanbul-Turkey.
}

Received: September 18, 2018

Accepted: September 27, 2018

Online Published: September 28, 2018

doi:10.5430/ijhe.v7n5p127

URL: https://doi.org/10.5430/ijhe.v7n5p127

This study was presented as a oral paper in the International Balkan Sport Science Conference in Bursa on 21-23 May 2017.

\begin{abstract}
There are two types of motivation, internal and external, differenetiated by the source of the motivation. For internal motivation, the job itself motivates the individual; for external motivation, the environment motivates that individual. Today, organizational trust is extremely important to increase organizational success as well as to create effectiveness and efficiency. Having a successful, effective, and efficient organization is greatly linked with trust between organization managers and employees. The purpose of this study was to investigate how the internal and external motivation of employees effects organizational trust levels. The study sample consisted of 164 employees working under the Youth Service and Sport Provincial Directorate of Bursa, Turkey. A survey was used to obtain data, which were analyzed with the SPSS 20 program. This study used the internal-external motivation and organizational trust scales. To measure the internal and external motivation levels of participants, a scale developed by Mottaz (1985) and a Turkish reliability-validity study conducted by Ersarı and Naktiyok (2012) were used. To measure organizational trust level, a scale developed by three different researchers (Whitener et al., 1998; Mayer et al., 1995; McAllister et al., 1995) and adapted to Turkish with a reliability and validity analysis by Tokgöz and Seymen (2013) was used. The independent t-test, ANOVA test, correlation and regression tests were used to analyze the data. Based on the correlation and regression analysis, both internal and external motivation had significant positive effects on organizational trust and its sub-dimensions. Accordingly, as the internal and external motivation of participants increased, organizational trust increased as well.
\end{abstract}

Keywords: internal motivation, external motivation, organizational trust, sport organizations

\section{Introduction and Purpose}

The main instinct of humans is to continue living. To achieve this, they need to work and earn money to meet their minimum needs. The main purpose of organizations is to increase efficiency and profit. Therefore, individuals and organizations need each other. Employee and organizational compliance provides various benefits to both parties, including saving time, decreasing costs, and increasing efficiency. It is important to combine the purposes of employees and business owners by providing optimum conditions for both parties that sustain peace and tranquility. Therefore, organizations need to effectively use human resources (Aydın et al., 2011; Boylu et al., 2007; Güllü and Koçak, 2016:1471; Karcıŏlu and Çelik, 2012).

Motivation is one of the key concepts to understand in human psychology (Çalışkur and Demirhan, 2013:53). This concept is defined as the driving power to stimulate and direct individuals to complete desired and needed behaviors in the work environment and sustain such behaviors. In addition, motivation can be understood as an effective force to bring an action or event into being (Aycan and Yıldız, 2016). Motivation can be considered in two types, internal and external, based on the source of the motivation. For internal motivation, the job itself motivates the individual; 
for external motivation, the environment motivates that individual (Ersarı and Naktiyok, 2012:83; Cengiz \& Kabakçı, 2014:61; Kolayiş \& Çelik, 2017:23; Kolayis, 2012).

External motivation refers to being motivated from rewards that come from the surrounding environment of the individual. Employee motivation can be increased by external rewards, such as receiving bonuses, promotions, work incentives, and appreciation. However, while external elements play an important role to increase one's motivation, without internal elements, external elements fail to provide necessary motivation (Ersar1 and Naktiyok, 2012:83, 84).

In the literature, there are various studies that analyze what effect and are effected by motivation. These study matter such as the internal motivation in social development and well-being (Ryan and Deci, 2000), motivation and leadership (Hofstede,1980), motivation and leadership tendencies (Özdemir et al., 2015), internal motivation and organizational identity (Argon and Ertürk, 2013); internal-external motivation and work satisfaction (Köroğlu, 2012), motivation and work satisfaction (Karaköse and Kocabaş, 2006), motivation in psychoviolance and peace (Yaman et al., 2010), motivation in efficiency (Özdemir and Muradova, 2008), motivation in performance evaluation (Tunçer, 2013); motivation in sports consumers (Polat and Yalçın, 2014). These studies showed relationships between motivation and other variables.

Under the current conditions in which rapid developments force organizations to change and innovate and to cope with these challenges, it is important for organizations to form relationships with employees that foster trust, loyalty, and increase satisfaction, rather than constraining such relationships (Çağlar, 2011:1828). High trust levels of employees contribute to organizational success.

Today, organizational trust is extremely important to increase organizational success as well as to create effectiveness and efficiency. Having a successful, effective, and efficient organization is greatly linked to trust between organization managers and employees. It is understood that organizational trust is related to the level of trust of employees in themselves and towards each other, and that effects organizational structure. Creating trust is among the fundamental topics that directly affect the organization's ability to compete with other organizations and survive. Higher performance in organizations in which employees trust themselves and others is possible if organizations can see the future with trust and survive under negative conditions (Asunakutlu, 2001:1, 11, 12).

Organization trust represents trust between organizations and within an organization. There are few dimensions in which interorganizational trust is evaluated. These are trust for the co-worker, trust for managers, and trust for the organization (Çubukçu and Tarakçığlu, 2010:58). Trust in the organization can refer to employees, managers, organizational functioning, procedures, and so forth. It is a known fact that trusted organizations are more successful (Cantaş and Kavas, 2015:920). Employee compliance to organizational change (Göksel et al., 2017) is important for forming organizational trust.

In the literature, there are studies showing relationships between organizational trust and motivation (Cantaş and Kavas, 2015:930), organizational commitment (Spence Laschinger et al., 2002), leadership (Joseph and Winston, 2005), organizational justice (DeConinck, 2010; Polat and Celep, 2008; Baş and Şentürk, 2011), perceived organizational support (DeConinck, 2010), organizational citizenship (Polat and Celep, 2008; Baş and Şentürk, 2011), ethical leadership (Yılmaz, 2006; Cemaloğlu and Kılınç, 2012; Teyfur et al., 2016), job satisfaction (Driscoll, 1978; Spence Laschinger et al., 2002; Yazıcıŏglu, 2009; Gider, 2010), intention to leave (Yazıcığlu, 2009), mobbing (Cemaloğlu and Kılınç, 2012), life satisfaction (Yılmaz and Sünbül, 2009), and organizational identity (Uğurlu and Arslan, 2015).

The main purpose of this study was to examine the effect of internal-external motivation level of sports organization employees on organizational trust levels.

\section{Material and Method}

\subsection{Study Scope}

The study sample consisted of 164 employees (123 male, 41 female) working under the Youth Service and Sport Provincial Directorate of Bursa, Turkey who gave informed consent to participation.

\subsection{Study Method}

A survey was used as the data collection tool of this study. The survey form consisted of three sections. The first section included internal and external motivation scale questions, the second section included trust scale questions, and the last section included demographic questions. To measure the internal and external motivation levels of participants, a scale developed by Mottaz (1985) and a Turkish reliability-validity study conducted by Ersarı and Naktiyok (2012) were used. 
To measure organizational trust level, a scale developed by three different researchers (Whitener et al., 1998; Mayer et al., 1995; McAllister et al., 1995) and adapted to Turkish with a reliability and validity analysis by Tokgöz and Seymen (2013) was used. In this study, organizational trust levels were considered for three dimensions: trust to managers, trust to co-workers, and trust to the organization. Because the reliability and validity of the above mentioned scale questions were repeatedly tested and analyzed in both national and international literature, the original scale dimensions were used in this study.

Survey questions were in 5-point Likert form with 1 referring to "Definitely disagree" and 5 referring to "Definitely agree." The data were analyzed with an SPSS program. Kolmogorov-Simirnov test results indicated that the data had a normal distribution ( $>0.05$ ). Reliability analysis, t-test, ANOVA, correlation, and regression statistical techniques were used.

\subsection{Hypothesis and Model}

The following hypothesis were tested under the scope of this study:

$\mathrm{H}_{1}$ : Internal motivation has positive effects on organizational trust.

$\mathrm{H}_{2}$ : Internal motivation has significant positive effects on the organizational trust sub-dimensions.

$\mathrm{H}_{2 \mathrm{a}}$ : Internal motivation has positive effects on the trust to managers sub-dimension.

$\mathrm{H}_{2 \mathrm{~b}}$ : Internal motivation has positive effects on the trust to co-workers sub-dimension.

$\mathrm{H}_{2 \mathrm{c}}$ : Internal motivation has positive effects on the trust to the organization sub-dimension..

$\mathrm{H}_{3}$ : External motivation has positive effects on organizational trust.

H4: External motivation has positive effects on the organizational trust sub-dimensions.

$\mathrm{H}_{4 a}$ : External motivation has positive effects on the trust to managers sub-dimension.

$\mathrm{H}_{4 \mathrm{~b}}$ : External motivation has positive effects on the trust to co-workers sub-dimension.

$\mathrm{H}_{4 \mathrm{c}}$ : External motivation has positive effects on the trust to the organization sub-dimension.

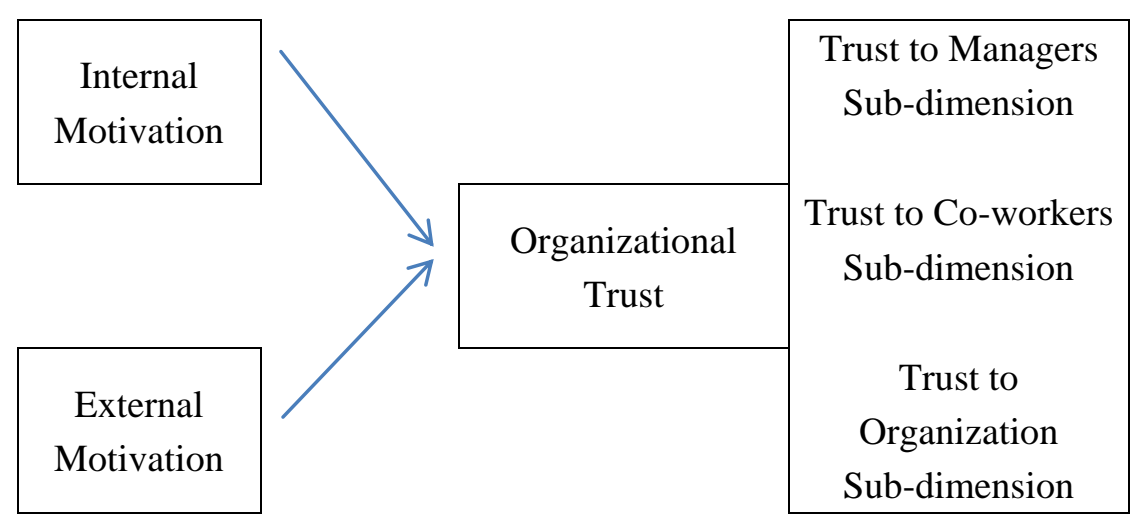

Figure 1. Research model 


\section{Findings}

\subsection{Statistical Analysis and Findings}

The demographic properties of the participants are given in Table 1.

Table 1. Demographic Properties of Participants

\begin{tabular}{|c|c|c|c|}
\hline Demographic Properties & Sub-properties & $N$ & $\%$ \\
\hline \multirow[t]{2}{*}{ Gender } & Female & 41 & 25 \\
\hline & Male & 123 & 75 \\
\hline \multirow[t]{4}{*}{ Age } & 20-30 years old & 38 & 23.2 \\
\hline & $31-40$ years old & 75 & 45.7 \\
\hline & $41-50$ years old & 39 & 23.8 \\
\hline & 51 years and older & 12 & 7.3 \\
\hline \multirow[t]{2}{*}{ Marital Status } & Married & 121 & 73.8 \\
\hline & Single & 43 & 26.2 \\
\hline \multirow[t]{7}{*}{ Educational Background } & Primary/Elementary School & 19 & 11.6 \\
\hline & High School & 35 & 21.3 \\
\hline & Associate Degree & 11 & 6.7 \\
\hline & Undergraduate Degree & 94 & 57.3 \\
\hline & Master Degree & 5 & 3.0 \\
\hline & $\begin{array}{l}\text { Director (Department Chief/Youth Center } \\
\text { Director etc) }\end{array}$ & 7 & 4.3 \\
\hline & Chief (Chief-Facility Manager) & 10 & 6.1 \\
\hline \multirow[t]{5}{*}{ Position } & Trainer-Lifeguard & 88 & 53.7 \\
\hline & Youth Leader & 4 & 2.4 \\
\hline & Officer & 20 & 12.2 \\
\hline & Technical Staff & 5 & 3.0 \\
\hline & $\begin{array}{l}\text { Service Staff } \\
\text { (Guard-Caretaker-Cleaner-Driver etc.) }\end{array}$ & 30 & 18.3 \\
\hline \multirow[t]{5}{*}{ Professional Seniority } & $1-5$ years & 76 & 46.3 \\
\hline & $6-10$ years & 52 & 31.7 \\
\hline & $11-15$ years & 17 & 10.4 \\
\hline & $16-20$ years & 5 & 3.0 \\
\hline & 21 years and more & 14 & 8.5 \\
\hline
\end{tabular}

Participant Sample: 164

According to Table 1 the majority of participants were male and between 31 and 40 years old. The majority of participants was married and had completed an undergraduate education. In terms of positions, half of the participants were trainer-lifeguards. In addition, it was common for the seniority level in the organization to be 1-5 years.

The reliability analysis of the scales adopted in the study was conducted and the Cronbach Alpha value is given at Table 2. 
Table 2. Reliability of Scales for Dimensions

\begin{tabular}{lllll}
\hline Dimensions & $\begin{array}{l}\text { Question } \\
\text { Number }\end{array}$ & $\begin{array}{l}\text { Cronbach } \\
\text { Alpha }(\alpha)\end{array}$ & Mean & $\begin{array}{l}\text { Standard } \\
\text { Deviation }\end{array}$ \\
\hline Internal Motivation Scale & 9 & 0.91 & 4.09 & 0.67 \\
External Motivation Scale & 15 & 0.87 & 3.42 & 0.65 \\
Organizational Trust Scale & 25 & 0.97 & 3.70 & 0.72 \\
Trust to Managers Dimension & 9 & 0.96 & 3.80 & 0.82 \\
Trust to Coworker Dimension & 8 & 0.94 & 3.73 & 0.76 \\
Trust to Organization Dimension & 8 & 0.93 & 3.56 & 0.84
\end{tabular}

As seen from Table 2, the Cronbach Alpha $(\alpha)$ coefficients for adopted scales were 0.91 for internal motivation, 0.87 for external motivation and 0.97 for organization trust. Based on these results, it was seen that the scales have a high level of reliability $(\alpha>0.70)$.

When the averages were considered, it was seen that the internal motivation levels of participants were higher than the external motivation levels. In addition, participants agreed more regarding the trust to the manager dimension statements.

The correlation analysis was conducted to determine the level and direction of the relationship between dependent and independent variables. It is summarized in the Table 3.

Table 3. Correlation Table

\begin{tabular}{llllll} 
Variables & 1 & 2 & 3 & 4 & 5 \\
\hline 1.Internal Motivation & 1 & & & \\
\hline 2.External Motivation & $0.569^{* *}$ & 1 & & & \\
\hline 3.Organizational Trust & $0.555^{* *}$ & $0.790^{* *}$ & 1 & & \\
\hline 4.Trust to Organization & $0.434^{* *}$ & $0.752^{* *}$ & $0.899^{* *}$ & 1 & \\
\hline 5.Trust to Managers & $0.553^{* *}$ & $0.726^{* *}$ & $0.927^{* *}$ & $0.784^{* *}$ & 1 \\
\hline 6.Trust to Coworkers & $0.487^{* *}$ & $0.620^{* *}$ & $0.832^{* *}$ & $0.598^{* *}$ & $0.655^{* *}$ \\
\hline
\end{tabular}

**Significance value is 0.01 .

Based on the correlation analysis results given in Table 3, it was determined that the relationship between internal motivation and organizational trust was a moderately positive relationship $(r=0.555)$ and the relationship between external motivation and organizational trust was a highly positive relationship $(\mathrm{r}=0.790)$. When sub-dimensions of organizational trust were considered, it was found that the relationship between internal motivation and trust to organization was moderately positive relationship $(\mathrm{r}=0.434)$, trust to managers was a positive relationship $(\mathrm{r}=0.553)$, and trust to co-workers was a moderately moderately positive relationship $(\mathrm{r}=0.487)$. It was found that the relationship between external motivation and trust to organization was a highly positive relationship ( $\mathrm{r}=0.752$ ), trust to managers was a highly positive relationship $(\mathrm{r}=0.726)$, and trust to co-workers was a moderately positive relationship ( $\mathrm{r}=0.620)$.

To test the effects of internal motivation and external motivation on organizational trust, a linear regression analysis was conducted. The analysis results are given in Tables 4 and 5.

Table 4. Effect of Internal Motivation on Organizational Trust

\begin{tabular}{llllllll} 
Variables & $\beta$ & $\mathrm{R}^{2}$ & Adjusted $\mathrm{R}^{2}$ & Standard Error & $\mathrm{F}$ & $\mathrm{p}$ \\
\hline Organizational Trust & .555 & .31 & .30 & .609 & 72.226 & 0.00 \\
\hline Trust to managers & .553 & .30 & .30 & .693 & 71.511 & 0.00 \\
\hline Trust to Coworker & .487 & .23 & .23 & .671 & 50.271 & 0.00 \\
\hline Trust to Organization & .434 & .18 & .18 & .763 & 37.688 & 0.00 \\
\hline
\end{tabular}

Independent Variable: Constant Variable and Internal Motivation 
Based on the regression analysis results in the Table 4 , there were statistically significant $(p<0.05)$ and positive $(\beta=0,555)$ effects of internal motivation on organizational trust. In addition, under this model, the internal motivation explained $30 \%$ of organizational trust.

In terms of dimensions, it was determined that internal motivation had a statistically significant $(p<0.05)$ and positive effect $(\beta=0.553, \beta=0.487, \beta=0.434)$ on the trust to managers, trust to co-workers, and trust for the organization sub-dimension of organizational trust. Internal motivation explained 30\% of the trust to managers, $23 \%$ of trust to co-workers, and $18 \%$ of trust to the organization. According to these results, hypotheses $\mathrm{H}_{1}$ and $\mathrm{H}_{2}$ were supported.

Table 5. Effect of External Motivation on Organizational Trust

\begin{tabular}{lllllll} 
Variables & $\beta$ & $\mathrm{R}^{2}$ & Adjusted $\mathrm{R}^{2}$ & Standard Error & $\mathrm{F}$ & $\mathrm{P}$ \\
\hline Organizational Trust & .790 & .63 & .62 & .455 & 269.425 & 0.00 \\
\hline Trust to managers & .726 & .527 & .52 & .572 & 180.797 & 0.00 \\
\hline Trust to Coworker & .620 & .384 & .38 & .602 & 101.184 & 0.00 \\
\hline Trust to Organization & .752 & .56 & .56 & .559 & 210.394 & 0.00 \\
\hline
\end{tabular}

Independent Variable: Constant Variable and External Motivation

Based on the regression analysis results in the Table 5, there were statistically significant $(p<0.05)$ and positive $(\beta=0,790)$ effects of external motivation on organizational trust. In addition, under this model, external motivation variable explained $62 \%$ of organizational trust variable.

It was found that external motivation had statistically significant $(p<0.05)$ and positive effects $(\beta=0.726, \beta=0.620$, $\beta=0.752)$ on the trust to managers, trust to co-workers, and trust for the organization sub-dimensions of organizational trust. External motivation explained 52\% of the trust to managers, 38\% of the trust to co-workers, and $56 \%$ of the trust tor the organization. According to these results, hypotheses $\mathrm{H}_{3}$ and $\mathrm{H}_{4}$ were supported.

On the other hand; according to the results of independent t-test and ANOVA test used to examine whether the internal-external motivation and organizational trust levels of the participants differ according to their demographic characteristics;

- Significant differences between organizational trust and gender $(\mathrm{p}=0.035<0.05)$ were observed. It was compared the averages, males $(3,75)$ were more likely to participate in organizational trust scale than females $(3,55)$.

- According to the independent t-test results between marital status and variables, it was significant differences between internal motivation $(\mathrm{p}=0.027<0.05)$, external motivation $(\mathrm{p}=0.011<0.05)$ and organizational trust $(\mathrm{p}=$ $0.001<0.05)$ were observed. Considering the averages, we can say that married people experience more internal-external motivation and organizational trust than single people.

\section{Discussion and Results}

According to the analysis, it was found that the internal motivation and external motivation of participants had positive effects on their trust towards their organization. In other words, as the internal or the external motivation levels of participants increased, their trust for the organization increased. In addition, internal motivation had the highest percentage of explaining the trust to managers sub-dimension while external motivation variable had the highest percentage of explaining trust to organization sub-dimension.

In addition, the motivation level of participants was above average and their agreement level with internal motivation scale statements was higher than their agreement level with external motivation scale statements. In other words, the Bursa Youth Services and Sport Provincial Directorate employees were more motivated internally.

The organizational trust of participants were higher than average. Trust to managers was higher than trust to co-workers and trust for the organization. This study is important to show how important managers and leaders are to an organization. On the other hand, it was observed that although there were positive relationships for both internal and external motivation regarding the organizational trust levels of participants, the relationship between external motivation and the organizational trust sub-dimensions was higher. This means that as the external motivation of participants increased, organizational trust increased as well. In other words, material and immaterial factors related to the organization affected trust towards organization more than the individual's own motivation. Internal motivation tools provided the highest percentage for explaining the trust to managers sub-dimension. This is regarded as a significant result. 
This is different from the findings of a study on hotel employees found that internal motivation tools were more effective on employee motivation, compared to external motivation tools (Dündar et al., 2007:15). There are certain studies that investigated the relationship between demographic variables and internal-external motivation and organizational trust level. The results from one of those studies showed that the agreement of female participants for the organizational trust scale was higher than male participants, and that agreement of married individuals to organizational trust and internal-external motivation scale was higher than single participants. Other than these findings, it was found that there was no significant difference for age, education level, position, seniority in organization, and occupational seniority. It was shown that internal-external motivation level of participants showed no difference for sex, age, duration in the business, and department (Dündar et al., 2007:15). In another study conducted on teachers, the levels of organizational trust in elementary school teachers were compared for sex and it was found that there was no significant difference for any sub-dimension or total scores (Bökeoğlu and Yılmaz, 2008:218).

In another study, the organizational trust and internal-external motivation scores of married participants were higher than single participants. The order and trust associated with marriage might influence the perception of individuals towards his or her work life. In a study conducted on 127 bank employees to measure the role of internal and external motivation on coping with stress, it was shown that internal motivation changed based on marital status and that married individuals had higher general internal motivation levels than single individuals (Ersarı and Naktiyok, 2012:99). In a study conducted on 930 teachers to measure the effect of organizational trust towards their school on motivation, it was found that there was statistically positive and bilateral relationship between all dimensions that determine the organizational trust level of teachers and all the dimension of motivation levels. In that study, it was found that the general organizational trust level of teachers had a significant positive effect on motivation levels. Accordingly, it was concluded that as organizational trust level of teachers increased, general motivation level increased as well (Cantaş and Kavas, 2015:930).

In a study that analyzed the role of organizational trust and cynicism of employees on organizational commitment, it was found that organizational trust perception and cynicism were extremely important variables on the organizational commitment behavior of employees. According to the results, organizational trust can significantly effect both feelings of organizational commitment and organizational cynicism. Cynic attitudes that are generally not preferred by organizations for employees might decrease employee trust. As seen from that study, employees like to trust the organization in their work place. Lack of trust in the organization or perceiving employers as mistrustful might cause mistrustful feelings in employees; therefore, causing these employees to question their commitment to the organization and show increased cynicism (Türköz et al., 2013:298).

According to a study conducted on hotel employees that analyzed the relationship between organizational trust and commitment, it was shown that the organizational commitment of employees was low when their trust was low. In organizations without sufficient organizational commitment, it is a common fact that desired employee performance and efficiency will be lacking (Çubukçu and Tarakçıŏlu, 2010:63).In another study conducted on teachers that analyzed the relationship between perceived organizational trust and mobbing by teachers regarding the ethical leadership behaviors of managers, it was found that ethical leadership and organizational trust had negative and significant effect on mobbing, and ethical school environment and trustful school atmosphere decreased mobbing perception of teachers. As school managers showed ethical leadership behaviors, the organizational trust level of teachers increased and this decreased mobbing. The ethical atmosphere brings together a trustful organization environment and is associated with less mobbing. Ethical leadership created an education organization with a high level of organizational trust and low level of mobbing, which then created a healthy work environment for teachers with direct and indirect effects to increase the academic quality in the school (Cemaloğlu and Kılınç, 2012:147).

The results of a study conducted in Taiwan with 428 employers empirically showed that regarding the significant influence of corporate citizenship on work engagement via the mediation of organizational trust, organizational trust can be properly used as an important checkpoint for detecting work engagement in corporate citizenship. Management should know that employees are very sensitive to any confusion about corporate social activities in which their organizational trust is weakened. For example, once management has detected employees' low trust in the organization, management should fortify corporate citizenship by showing the organization's core values to the employees in order to win their trust. Perceived economic citizenship has positive impacts on both organizational trust and work. Engagement suggests that the fundamental substantiality of the individual's economic needs should be the first priority among all business issues. Despite the job opportunities provided by the organization, management should also bear in mind the individuals' career development and advancement when facilitating their organizational trust and work engagement. The positive influence of perceived discretionary citizenship on both 
organizational trust and work engagement exhibits that discretionary citizenship helps to increase employees' morale, organizational trust and work engagement. This empirical finding is very important for understanding work engagement that is seldom examined with an antecedent related to external discretionary behavior (i.e., discretionary citizenship) (Lin, 2010:526,527).

Another study found that alliance formation moderates the relationship between organizational trust and interfirm cooperation, suggesting that while trust plays a facilitating role in enhancing cooperation under conditions of low competitive intensity (i.e., vertical alliances), it has little effect on cooperation under highly competitive conditions (i.e., horizontal alliances). Thus, even if participants place a great deal of trust in their fellow collaborators, this trust only enhances cooperation when firms are collaborating with channel members. This suggests that in place of organizational trust, collaborators in horizontal relationships rely on institutional or interpersonal supports to ensure cooperation with competitors. Thus, the effect of organizational trust on interfirm cooperation appears to be dependent upon the type of alliance a firm is participating in (Rindfleisch, 2000:91).

In another study, it was found that organizational trust plays an important role in defining the service climate of hotel organizations (Chathoth vd, 2007:354,355). To study on the development of organizational justice among employers, it is essential to understand the socio-cultural context, particularly the level of work morale, when organizational trust is investigated as well as built by management in an actual organization. Trust relationships are context-determined and this aspect is of great importance for overall organizational success. The approach that we present here describes the development process of organizational trust in a low work morale context. However, the context-sensitive model of organizational trust developed in this paper indicates that there are also other development processes such as from the mismatch of high organizational trust in employees and low work morale of them to a match, as well as from the mismatch of low organizational trust in employees and high work morale of them to a match. We conclude that these processes should be clarified and investigated in the future (Lamsa et all., 2006:139).

As a result, precautions should be taken to minimize the negative behavior of organizations. This is necessary for peace and tranquillity as well as decreasing costs of organizations (Güllü, 2018a). The trust environment provided by organizations to employees is extremely important for these organizations to reach their work objectives. This management and co-worker trust reflects on work motivation. A work environment with peace, tranquillity, and trust will have positive outputs in the organization environment. Positive behaviors such as organizational commitment will increase, and negative behaviors such as leaving work and non-productive behavior will decrease. As Rego et al. (2011:529) stated, determining the main roots of an efficient relationship between healthy individuals and healthy organizations will create a stronger organizational behavioral science (Güllü, 2018b:555). In a work environment with organizational compliance, organizational peace and tranquillity, open communication channels, and self-expression of employees, individuals have a high level of trust towards their managers and organizations. This brings together positive emotions and behaviors and contributes to organizational efficiency. It is recommended to conduct similar studied on organizations and employees with different structure.

\section{References}

Argon, T., \& Ertürk, R. (2013). İlköğretim okulu öğretmenlerinin içsel motivasyonları ve örgütsel kimliğe yönelik alg1ları. Kuram ve Uygulamada Egitim Yönetimi Dergisi, 19(2), 159-179.

Asunakutlu, T. (2001). Klasik ve neo-klasik dönemde örgütsel güvenin karşılaştırılması üzerine bir deneme. Sosyal ve Beşeri Bilimler Araştirmalari Dergisi, 1(5).

Aycan, A. \& Yıldız, K . (2016). 11-14 yaş grubu öğrencilerin spora katılım motivasyonlarının cinsiyetleri açısından incelenmesi. International Journal of Social Science Research, 5(2), 1-9.

Aydın, A., Sarıer, Y. \& Uysal, G. (2011). The effect of gender on organizationa lcommitment of teachers: a meta analytic anlaysis. Educaional Sciences: Theory\&Practice, 11(2), 628-632.

Baş, G., \& Şentürk, C. (2011). İlköğretim okulu öğretmenlerinin örgütsel adalet, örgütsel vatandaşl1k ve örgütsel güven algıları. Kuram ve Uygulamada Egitim Yönetimi Dergisi, 17(1), 29-62.

Boylu, Y., Pelit, E. \& Güçer, E. (2007). Akademisyenlerin örgütsel bağlılık düzeyleri üzerine bir araştırma. Finans, Ekonomi Ve Ekonomik Yorumlar Dergisi, 44(511), 55-74

Bökeoğlu, Ö. Ç., \& Yılmaz, K. (2008). İlköğretim okullarında örgütsel güven hakkında öğretmen görüşleri. Kuram ve Uygulamada Egitim Yönetimi Dergisi, 14(2), 211-233. 
Cantaş, C., \& Kavas, E. (2015). Ortaokullarda görev yapan öğretmenlerin örgütlerine duydukları güvenin motivasyonları üzerindeki etkileri: afyonkarahisar ili uygulaması. Uluslararası Sosyal Araştırmalar Dergisi, 8(41), 920-938.

Cemaloğlu, N., \& Kılınç, A. Ç. (2012). İlköğretim okulu yöneticilerinin etik liderlik davranışları ile öğretmenlerin algıladıkları örgütsel güven ve yıldırma arasındaki ilişki. Eğitim ve Bilim, 37(165).

Cengiz, R., \& Kabakçi, A. C. (2014). Üniversiteler arasi futsal müsabakalarina katilan sporcularin başari yönelim ve motivasyon davranişlarinin incelenmesi. SSTB International Refereed Academic Journal of Sports, Health \& Medical Sciences, 13(4).

Chathoth, P. K., Mak, B., Jauhari, V. \& Manaktola, K. (2007). Employees' perceptions of organizational trust and service climate: A structural model combining their effects on employee satisfaction. Journal of Hospitality \& Tourism Research, 31(3), 338-357. https://doi.org/10.1177/1096348007299922

Çağlar, Ç. (2011). Okullardaki örgütsel güven düzeyi ile öğretmenlerin mesleki tükenmişlik düzeyinin bazı değişkenler açısından incelenmesi. Kuram ve Uygulamada Eğitim Bilimleri, 11(4), 1827-1847.

Çalışkur, A., \& Demirhan, A. (2013). Içsel güdülenme envanteri dilsel eşdeğerlik, güvenirlik ve geçerlik çalışması. Uşak Üniversitesi Sosyal Bilimler Dergisi, 2013(16):52-74.

Çubukçu, K., \& Tarakçioğlu, S. (2010). Örgütsel güven ve bağl1lık ilişkisinin otelcilik ve turizm meslek lisesi öğretmenleri üzerinde incelenmesi. İşletme Araştırmaları Dergisi, (4), 57-78.

DeConinck, J. B. (2010). The effect of organizational justice, perceived organizational support, and perceived supervisor support on marketing employees' level of trust. Journal of Business Research, 63(12), 1349-1355. https://doi.org/10.1016/j.jbusres.2010.01.003

Driscoll, J. W. (1978). Trust and participation in organizational decision making as predictors of satisfaction. Academy of management journal, 21(1), 44-56.

Dündar, S., Özutku, H., \& Taşpınar, F. (2007). İçsel ve dışsal motivasyon araçlarının işgörenlerin motivasyonu üzerindeki etkisi: ampirik bir inceleme. Ticaret ve Turizm Eğitim Fakültesi Dergisi, 2, 105-119.

Ersarı, G., \& Naktiyok, A. (2012). Iş görenin içsel ve dışsal motivasyonunda stresle mücadele tekniklerinin rolü/role of stress fighting tecniques in internal and external motivation of employees. Atatürk Üniversitesi Sosyal Bilimler Enstitüsü Dergisi, 16(1).

Gider, Ö. (2010). Eğitim ve araştırma hastanelerinde çalışan personelin örgütsel bağlllık, örgütsel güven ve iş doyum düzeylerinin araştırılması. Yönetim: İstanbul Üniversitesi İşletme İktisadı Enstitüsü Dergisi-1975'ten Bugüne, 21(65).

Göksel,A.G., Caz.Ç., Yazıcı, O.F. \& Kayhan, R.F. (2017). Örgütsel değişime uyum: spor bilimleri alanında çalışan akademik personeller üzerine bir uygulama. The Journal of Academic Social Science Studies, 58, 489-496.

Guido, M., Reinhard, B., \& Hee, L. S. (2004). Understanding organizational trust-foundations, constellations, and issues of operationalization. Journal of Managerial Psychology, 19(6), 556-570. https://doi.org/10.1108/02683940410551480

Güllü, S. (2018a). Counterproductive behaviors: A case study of a private sports business. International Journal of Social Sciences and Education Research, 4(2), 393-404. https://doi.org/10.24289/ijsser.427560

Güllü, S. (2018b). Spor işletmelerinde çalışan mutluluğu. International Journal of Social Sciences and Education Research, 4(3), 547-559. https://doi.org/10.24289/ijsser.428854

Güllü, S., \& Koçak, M. (2016). Examining Turkish professional volleyball players' levels of organizational commitment to their clubs. International Journal of Social Sciences and Education Research, 2(4), 1470-1484. https://doi.org/10.24289/ijsser.278994

Hofstede, G. (1980). Motivation, leadership, and organization: do American theories apply abroad? Organizational dynamics, 9(1), 42-63. https://doi.org/10.1016/0090-2616(80)90013-3

Joseph, E. E., \& Winston, B. E. (2005). A correlation of servant leadership, leader trust, and organizational trust. Leadership \& Organization Development Journal, 26(1), 6-22. https://doi.org/10.1108/01437730510575552

Karaköse, T., \& Kocabaş, İ. (2006). Özel ve devlet okullarinda öğretmenlerin beklentilerinin iş doyumu ve motivasyon üzerine etkileri. Eğitimde Kuram ve Uygulama, 2(1), 3-14. 
Karcıoğlu, F. \& Çelik, Ü.H. (2012). Mobbing (yıldırma) ve örgütsel bağlllığa etkisi. Atatürk Üniversitesi Iktisadi ve Idari Bilimler Dergisi, 26(1), 59-75.

Kolayis, H. (2012). Examining how wheelchair basketball players'self-esteem and motivation levels impact on their state and trait anxiety levels. Biology of Sport, 29(4). https://doi.org/10.5604/20831862.1019884

Kolayiş, H., \& Çelik, N. (2017). Examination of motivation, anxiety and imagery levels of footballers from different leagues. Revista de psicología del deporte, 26(3), 23-27.

Köroğlu, Ö. (2012). İçsel ve dışsal iş doyum düzeyleri ile genel iş doyum düzeyi arasındaki ilişkinin belirlenmesi: turist rehberleri üzerinde bir araştırma. Doğuş Üniversitesi Dergisi, 13(2), 275 - 289.

Lämsä, A. M., \& Pučètaite, R. (2006). Development of organizational trust among employees from a contextual perspective. Business Ethics: A European Review, 15(2), 130-141. Lämsä, A. M., \& Pučètaitè, R. (2006). Development of organizational trust among employees from a contextual perspective. Business Ethics: A European Review, 15(2), 130-141. https://doi.org/10.1111/j.1467-8608.2006.00437.x

Lin, C. P. (2010). Modeling corporate citizenship, organizational trust, and work engagement based on attachment theory. Journal of Business Ethics, 94(4), 517-531. https://doi.org/10.1007/s10551-009-0279-6

Mayer, Roger C., Davis James H. \& Schoorman F. David. (1995). An Integrative Model of Organizational trust. Academy ol Management Review, (20), 3, 709-734.

McAllister, Daniel J. (1995). Affect- and cognition-based trust as foundations for interpersonal cooperation in organizations. Academy of Management Journal, 38, 1, 24-59.

Mottaz, J. C. (1985). The relative importance of intrinsic and extrinsic rewards as determinants of wok satisfaction, The Sociological Quarterly, 26(3), 365-385. https://doi.org/10.1111/j.1533-8525.1985.tb00233.x

Özdemir, S., \& Muradova, T. (2008). Örgütlerde motivasyon ve verimlilik ilişkisi. Journal of Qafqaz University, (24).

Özdemir Özkan, N., Akın, S., \& Durna, Z. (2015). Hemşirelik öğrencilerinin liderlik yönelimleri ve motivasyon düzeyleri. Koç Üniversitesi Hemşirelikte Ĕgitim ve Araştırma Dergisi (HEAD), 12(1), 51-61.

Polat, S., \& Celep, C. (2008). Ortaöğretim öğretmenlerinin örgütsel adalet, örgütsel güven, örgütsel vatandaşlık davranışlarına ilişkin algıları. Kuram ve Uygulamada Egitim Yönetimi Dergisi, 14(2), 307-331.

Polat, E., \& Yalçın, H. B. (2014). Spor seyircileri için dışsal güdü ölçeği ve spor seyircileri için içsel güdü ölçeği geçerlik ve güvenilirlik çalışması. International Journal of Human Sciences, 11(1), 105-127. https://doi.org/10.14687/ijhs.v11i1.2693

Rindfleisch, A. (2000). Organizational trust and interfirm cooperation: an examination of horizontal versus vertical alliances. Marketing Letters, 11(1), 81-95. https://doi.org/10.1023/A:1008107011529

Ryan, R. M., \& Deci, E. L. (2000). Self-determination theory and the facilitation of intrinsic motivation, social development, and well-being. American psychologist, 55(1), 68. https://doi.org/10.1037/0003-066X.55.1.68

Spence Laschinger, H. K., Finegan, J., \& Shamian, J. (2002). The impact of workplace empowerment, organizational trust on staff nurses' work satisfaction and organizational commitment. In Advances in Health Care Management (pp. 59-85). Emerald Group Publishing Limited. https://doi.org/10.1016/S1474-8231(02)03006-9

Teyfur, M., Beytekin, O. F., \& Yalçinkaya, M. (2013). İlköğretim okul yöneticilerinin etik liderlik özellikleri ile okullardaki örgütsel güven düzeyinin incelenmesi (izmir il örneği). Dicle University Journal of Ziya Gokalp Education Faculty, 21.

Tokgöz, E. \& Seymen O. A. (2013). Örgütsel güven, örgütsel özdeşleşme ve örgütsel vatandaşlık davranış1 arasındaki ilişki: Bir devlet hastanesinde araştırma. Öneri Dergisi, 10(39), 61-76.

Tunçer, P. (2013). Örgütlerde performans değerlendirme ve motivasyon. Sayıştay Dergisi, 88(1), 87-108.

Türköz, T., Polat, M., \& Coşar, S. (2013). Çalışanların örgütsel güven ve sinizm algılarının örgütsel bağll1ıkları üzerindeki rolü. Yönetim ve Ekonomi: Celal Bayar Üniversitesi İktisadi ve İdari Bilimler Fakültesi Dergisi, 20(2), 285-302.

Uğurlu, C. T., \& Arslan, C. (2015). Öğretmenlerin örgütsel kimlik ve okula güven düzeylerinin bazı değişkenler açısından incelenmesi. Illkögretim Online, 14(1). 
Whitener, Ellen M., Brodt, Susan E., Korsgaard, M. Audrey \& Werner, Jon M. (1998). Managers as initiators of trust: an exchange relationship framework for understanding managerial trustworthy behavior. Academy of management, The Academy of Management Review, 23(3), 513.

Yaman, E., Vidinlioğlu, Ö., \& Çitemel, N. (2010). İşyerinde psikoşiddet, motivasyon ve huzur: Öğretmenler çok şey mi bekliyor? Psikoşiddet mağduru öğretmenler üzerine. Uluslararası İnsan Bilimleri Dergisi, 7(1), 1136-1151.

Yazicioğlu, İ. (2009). Konaklama işletmelerinde işgörenlerin örgütsel güven duygulari ile iş tatmini ve işten ayrilma niyetleri üzerine bir alan araştirmasi. Elektronik Sosyal Bilimler Dergisi, 30(30).

Y1lmaz, E. (2006). Okullardaki örgütsel güven düzeyinin okul yöneticilerinin etik liderlik özellikleri ve bazı değişkenler açısından incelenmesi (Doctoral dissertation, Selçuk Üniversitesi Sosyal Bilimler Enstitüsü).

Yilmaz, E., \& Sünbül L, A. M. (2009). Öğretmenlerin yaşam doyumlari ve okullardaki örgütsel güven düzeyi. Qafqaz University Publications, 172. 